\title{
Influence of Common Interest Group Membership on Productivity of Smallholder Indigenous Chicken Enterprise in Kisumu County
}

\author{
Onyango R ${ }^{1}$, Obara $\mathbf{J}^{2}{ }^{2}$, Bebe B.O ${ }^{3}$ \\ ${ }^{1,2,3}$ EgertonUniversity, Faculty of Education and Community, Njoro -Egerton Road, Nakuru, Kenya
}

\begin{abstract}
Common Interest Groups are farmers with common interest who come together in order to increase farm productivity. Broad objective of this research was to determine influence of Common interest group membership on productivity of indigenous chicken among smallholder farmers. This Study was carried out in Kisumu County Kenya, through cross-sectional survey research design, on 135 randomly selected respondents from indigenous chicken group members. Open and closed-ended questionnaires were used to collect primary data. Data analysis used both descriptive and inferential statistics. Chi-square test tested correlation between membership and management practices while t-test tested significant difference on Indigenous chicken products, by-products and level of income. Study findings indicated positive influence of group membership on indigenous chicken productivity characterized by better management practices, resulting to increased number of products and income from the enterprise. In conclusion, being a member of indigenous chicken Common Interest Group influences positively on management practices, improved volumes of products and byproducts resulting to improved profit margins from the enterprise.
\end{abstract}

Keywords: Common interest groups, Indigenous chicken, Productivity, Influence.

\section{Introduction}

\subsection{Background Information}

Agriculture directly influences economic growth, poverty reduction and environmental sustainability [15]. Kenya government not only consider agriculture as a key economic growth driver in achieving Sustainable Development Goals (SDGs), but also one of the strategies in the economic pillars of Vision 2030. In Kenya, various agricultural extension approaches have been used since 1902 to improve agricultural production. National Agriculture and Livestock Extension Programme (NALEP) funded both by Kenyan government and the Swedish Development Co-Operation (SIDA)had several objectives. One of which was to improve economic growth and livelihood of the poor. One of its implementation frameworks was formation of Common Interest Group (CIGs) to transform subsistence farming into profitable commercial enterprise through increased productivity [8].Farmer groups in Kenya like in other partsof the world were formed mainly with a social and economic function [2]. The main objective of the study was to determine the influence of common interest group membership on indigenous chicken productivity among smallholder farmers. In Kenya, $50 \%$ and $60 \%$ of meat and eggs respectively come from indigenous chicken(IC) [3] whose rearing can be a reliable, affordable, and easier to manage and source of household income. Though over $90 \%$ of small-scale farmers engage in IC rearing, very few of them consider it a commercial enterprise. Indigenous chicken production represents an important system for supplying the fast growing human population with quality protein and income [4].

A study by [9] showed that those who joined common interest groups achieved higher production levels and that the groups had increased chances to accessing new technologies. Research findings by [9] on common interest groups influence on implementation of crop production technologies; showed that the approach had a significant and positive influence on crop production. A study by [11] on the social and economic impacts of common interest group approach to extension service in Kenya showed that members of common interest groups had significantly increased access to extension services in general.

Indigenous chicken (Gallus domesticus) play important roles in the livelihood of rural households in western Kenya [12]. The findings of the study may assist policy makers, development planners, add new knowledge to the existing literature and assist in formulating proper and sound strategies to improve common interest group approach with the aim of increasing indigenous chicken productivity. The study findings indicated a positive influence of group membership on indigenous chicken productivity. In conclusion, members of Common Interest Groups benefited than before membership as a result of their participation in group activities.

\subsection{Statement of the Problem}

NALEP used resources to train small scale farmers within different focal areas in order to transform subsistence farming into market oriented and income driven enterprises. It encouraged the formation of Common Interest Groups (CIGs) in order to involve the members in joint training, production and marketing of various products. When farmers come together through indigenous chicken common interest groups, it is expected that this would influence productivity of indigenous chicken. However influence of common interest group membership on indigenous chicken productivity among smallholder farmers' remains unclear despite efforts put in promoting membership since 2002, hence the reason for the study. 


\section{International Journal of Science and Research (IJSR) \\ ISSN (Online): 2319-7064}

Index Copernicus Value (2013): 6.14 | Impact Factor (2014): 5.611

\subsection{Purpose of the Study}

To determine the influence of Common Interest Group membership on productivity from smallholder indigenous chicken enterprise in Kisumu East Sub- county, Kisumu County.

\section{3 Objectives of the Study}

The following specific objectives guided the study.

1) To determine the influence of Common Interest Group membership on indigenous chicken management practices.

2) To determine the influence of Common Interest Group membership on quantity of product and by-products from indigenous chicken enterprise.

3) To determine influence of CIG membership on income from indigenous chicken enterprise.

\subsection{Hypotheses}

The study was guided by hypotheses derived from the study objectives:

Ho . Common Interest Group membership has no statistically significant influence on indigenous chicken enterprise management practices.

$\mathbf{H o}_{2}$. Common Interest Group membership has no statistically significant influence on quantity of products and by-products produced from indigenous chicken enterprise.

$\mathbf{H O}_{3}$. Common Interest Group membership has no statistically significant influence on income from indigenous chicken enterprise

\subsection{Significance of the Study}

Indigenous chicken (Gallus domesticus) play important roles in the livelihood of rural households in western Kenya [13]. By documenting the influence of Common Interest Group membership on smallholder indigenous chicken productivity, future extension programmes that would transform indigenous chicken from subsistence to commercial may apply and promote the approach. Other extension providers may use the findings to enhance the packaging and delivery of technologies and other services. Implementers of participatory extension approach may use the finding to consolidate the benefits of group approach and use of CIGs. This may scale-up to other Sub- Counties and farmer groups in agricultural sub- sectors. The study may enable farmers to make informed choices regarding membership, which may help them access technologies, network with other key players in the agricultural sector, improve their income and food security thus reducing poverty levels within the sub-county and other similar parts of the country.

\section{Research Methodology}

\section{Introduction}

This chapter is presented in five distinct sections, the research design, description of the study area, population, sampling design and technique, data collection and statistical analysis.

\subsection{Research Design}

The study used a cross-sectional survey research designwhere data was collected from same CIGMember in Kisumu East Sub- County.Data was collected from CIGmembers in a single point in time and each person had a chance of being selected in the study representative of the larger Population in Kisumu East Sub- County.

\subsection{Location/Area of the study}

This study was carried out in Kisumu East Sub -County which is one of the Sub-Counties in Kisumu County. It covers an area of $557.7 \mathrm{~km}^{2}$ with estimated population of 453,593 and receives a mean rainfall of $1200 \mathrm{~mm}$ per year.

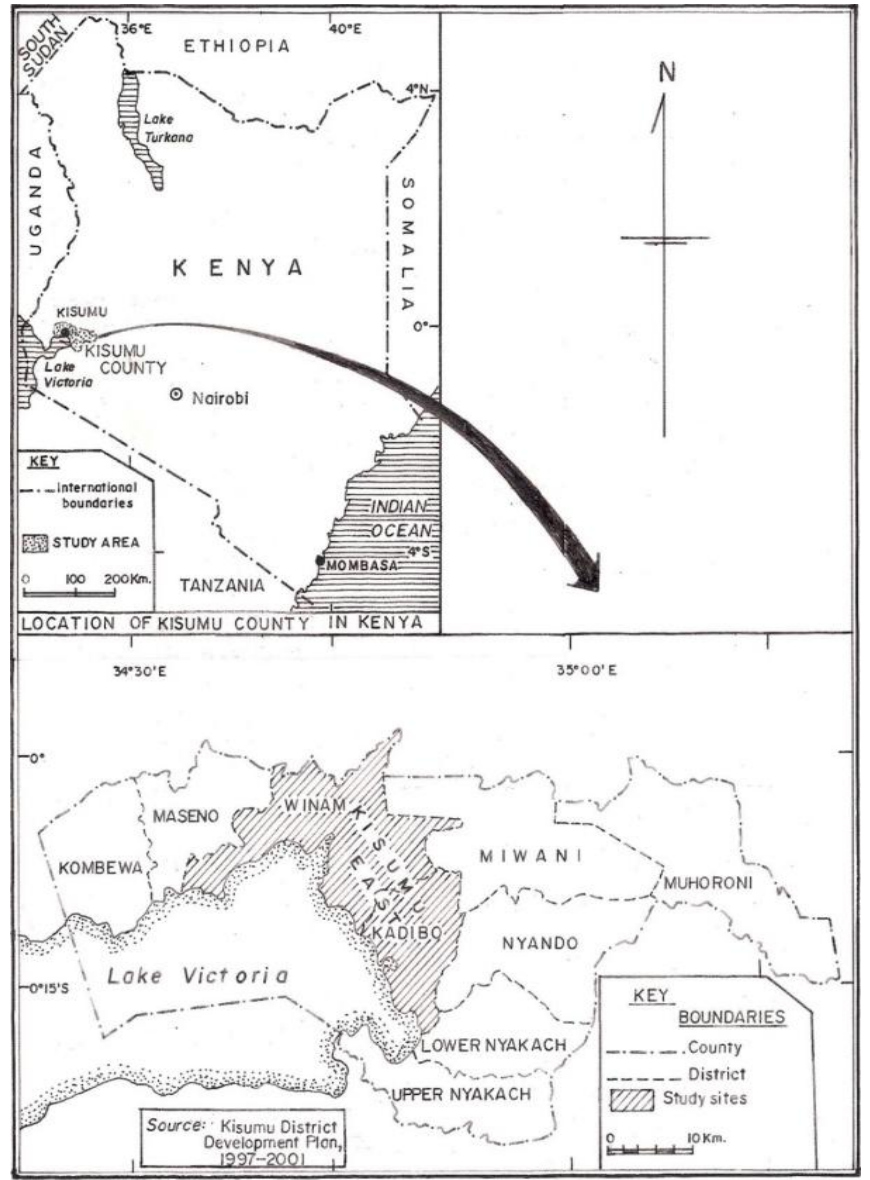

Figure 1: Map Showing the Location of Kisumu East SubCounty in Kenya

\subsection{Sampling Procedures and Sample Size}

The sampling frame was drawn from 400 smallholder farmers keeping indigenous chicken from the existing 20 active indigenous chicken CIGs. The required sample size was determined by using simplified formula for proportions by [14], at $95 \%$ confidence level and $\mathrm{P}=0.5$ are assumed for the equation i.e.

$$
n=\frac{N}{1+N(e)^{2}}
$$




\section{International Journal of Science and Research (IJSR) \\ ISSN (Online): 2319-7064 \\ Index Copernicus Value (2013): 6.14 | Impact Factor (2014): 5.611}

Where $\mathrm{n}$ is the sample size, $\mathrm{N}$ is the population size, and (e) is the level of precision. The study adopted precision level of $\pm 7 \%$. The sample size was calculated as below.

$\bar{n}=400 / 1+400(0.07)^{2}=135$ respondents. The computation yielded $n=135$ respondents. $+7 \%$ precision level was chosen based on previous studies [7] that approximately $80 \%$ of the households keep indigenous chicken in Western Kenya. Simple random sampling was then used to proportionately get 135 respondents from the Interest Groups.

\subsection{Instrumentation}

A questionnaire comprising of six open-ended and four closed-ended questions reflecting the objectives of the study was used to collect primary data from the sampled respondents.

\subsection{Data Collection}

The study used primary data, collected using both structured and unstructured questionnaire, it also used observation method which helped the researcher to validate the member's responses. The data collected included general member's information, indigenous chicken management practices, products and by-products and income.

\subsection{Data Analysis}

Data was analyzed using both descriptive and inferential statistics. Descriptive Statistics was used to describe demographic characteristics of respondents. Chi-square analysis was used to test association of indigenous management practices with membership while t- test was used to assess and compare differences in products and byproducts and income from indigenous chicken enterprise between common interest group before and after membership at confidence level of $95 \%(\mathrm{p} \leq 0.05)$.

\section{Results and Discussions}

\subsection{Demographic and characteristic of the Study Respondents.}

The variables studied under this included gender of the respondents, their highest educational level and age and their main reasons for keeping indigenous chicken before and as CIG member. The distribution of the demographic profile is shown below.

Table 1: Demographic Profile of the Respondents ( $\mathrm{n}=135)$

\begin{tabular}{|c|c|c|c|}
\hline Variable & Category & Frequency & Percentage \\
\hline \multirow{3}{*}{ Age in years } & $20-40$ & 42 & 31.2 \\
\cline { 2 - 4 } & $41-60$ & 73 & 54.2 \\
\cline { 2 - 4 } & $>61$ & 20 & 14.4 \\
\hline \multirow{3}{*}{ Gender } & Female & 88 & 65.7 \\
\cline { 2 - 4 } & Male & 47 & 34.4 \\
\hline \multirow{3}{*}{$\begin{array}{c}\text { Educational } \\
\text { Level }\end{array}$} & None & 9 & 6.9 \\
\cline { 2 - 4 } & Primary & 47 & 34.8 \\
\cline { 2 - 4 } & Secondary & 63 & 46.6 \\
\cline { 2 - 4 } & Tertiary & 16 & 11.9 \\
\hline
\end{tabular}

The mean age was 46.68 (standard deviation11.96) years, the youngest being 20 years and the oldest 73 years. The mean age of 46.68 years may imply that indigenous chicken rearing would be very productive since these are farmers in the productive age category. Young farmers below thirty years of age were few, a situation that could be attributed to rural urban migration of the youth in search of white collar jobs. Age as a variable is known to affect farm level decisions, group participation and access to technology. It also influences the capacity to join CIG and roles played by the farmer in CIG activities [11].

The number of male respondents was 47 representing $34.8 \%$ of the sample while 88 females representing $65.2 \%$. The enterprise is famous with women and even culturally, women prefer it over other enterprises that might require more resources. This finding agrees with [5] that more women than men participate in the production of indigenous chicken in Ethiopia.

The study indicates a high level of literacy among the sampled CIG members since majority of them (46.7\%) had attained secondary and primary (34.8\%) levels of education and only $7 \%$ were literacy challenged. The variable supported other studies that there is a link between education level and personal empowerment to increase agricultural production to escape poverty as suggested by [10]

The results indicated that $20.6 \%$ before joining CIG kept indigenous chicken for commercial purpose while (83.7\%) after joining CIG kept the same for commercial (Figure 1).

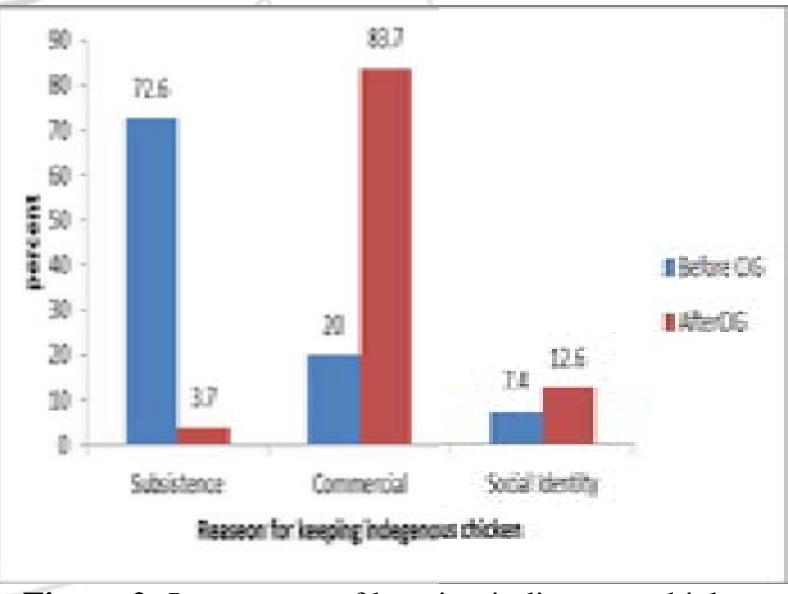

Figure 2: Importance of keeping indigenous chicken $(n=135)$

Conversely the proportion of members who kept poultry for subsistence declined from $72.6 \%$ before joining CIG to 3.7\% after joining CIG. Proportion of farmers who kept indigenous poultry for social identity did not significantly improve after joining (7.4\% before joining compared to $12.6 \%$ after joining $(\mathrm{P}=0.6727)$. this may imply that joining CIG changes members management practices from subsistence to commercial.

\subsection{Influence of CIG Membership on Indigenous Chicken Management Practices}

Management practices investigated were; source of breeding cocks, housing, vaccination, purchased supplementary feeds and practice of artificial brooding. The study found that 


\section{International Journal of Science and Research (IJSR) \\ ISSN (Online): 2319-7064 \\ Index Copernicus Value (2013): 6.14 | Impact Factor (2014): 5.611}

80.7\% respondents out of 135 sampled used own hatched and reared cocks before joining CIG while as CIG member it is significant that only $5.9 \%$ still used own hatched and reared indigenous cocks for breeding.Relatively $18.5 \%$ respondents purchased indigenous cocks for breeding before joining CIG while as CIG member $44.4 \%$ purchased indigenous breeding cocks.Proportion of farmers who did not have a house to rear poultry were $82.2 \%$, before joining and $7.4 \%$ after joining CIG $(\mathrm{p}<0.0001)$. Out of the 135 respondents, $16.3 \%$ had indigenous chicken house without a run before joining CIG while $47.4 \%$ had chicken house with a run. The result concurs with [13] that farmers should be equipped with knowledge and skills for improved productivity. $73.3 \%$ did not practice indigenous chicken vaccination before joining the groups, while $41.5 \%$ respondents occasionally vaccinated their birds after joining group. A small number of $21.5 \%$ regularly vaccinated their chicken even after joining CIG. This result is similar to findings by [3], that most farmers do not practice regular indigenous chicken vaccination even after being capacity built. 54.8\%occasionally practiced supplementary feeding to their chicken after joining CIG, while $77 \%$ did not practice supplementary feeding before joining the CIG as in Table 2.

The improvement in number of members $34.8 \%$ that partially practiced artificial brooding after joining CIG may be associated with the way farmers are capacity built when in common interest group. Before joining CIG majority of the members reported that they had not purchased poultry equipment $86.9 \%$ while as CIG members $85.1 \%$ purchased poultry equipment.

Table 2: Chi-square test on influence of CIG membership on Management Practices (n=135)

\begin{tabular}{|c|c|c|c|c|}
\hline & & $\begin{array}{c}\text { Before joining } \\
\text { CIG }\end{array}$ & $\begin{array}{c}\text { After joining } \\
\text { CIG }\end{array}$ & $\begin{array}{c}\text { Chi-square Test } \\
\text { (Mcnemars) P value }\end{array}$ \\
\hline Source of breeding cocks & Own hatched and reared indigenous cocks & 80.7 & 5.9 & $<0.0001$ \\
\cline { 2 - 5 } & Purchased indigenous cocks & 18.5 & 44.4 & 0.0241 \\
\cline { 2 - 5 } & Own reared exotic cocks & 0.7 & 21.5 & $<0.0001$ \\
\cline { 2 - 5 } & Purchased exotic cocks & 82.2 & 7.4 & NA \\
\hline Housing for indigenous & No housing & 16.3 & 47.4 & 0.0001 \\
chicken & Housing without a run & 1.5 & 45.2 & $<0.0001$ \\
\hline Vaccination of indigenous & Housing with a run & 73.3 & 1.5 & 0.0254 \\
chicken & Not practiced & 25.9 & 41.5 & 0.1303 \\
& Occasionally practiced & 0.7 & 21.5 & $<0.0001$ \\
\hline Practiced supplementary & Regularly practiced & 77.0 & 1.5 & 0.0138 \\
feeding & Not practiced & 23.0 & 54.8 & 0.0028 \\
& Occasionally practiced & 0 & 43.0 & NA \\
\hline Practice of artificial & Regularly practiced & 95.6 & 34.8 & $<0.0001$ \\
brooding & Not practiced & 3.7 & 37.8 & 0.1265 \\
\hline Purchase of indigenous & Occasionally practiced & 0.7 & 27.4 & $<0.0001$ \\
\hline chicken equipment & Regularly practiced & 86.3 & 85.1 & $<0.0001$ \\
\hline
\end{tabular}

Members significantly shifted from using own hatched and reared indigenous cocks before joining CIG for breeding to purchase of indigenous cocks and rearing or purchase of exotic cocks $(\mathrm{p}=0.0001)$ for breeding. Percentage of farmers who did not have a house to rear poultry significantly declined from $82.2 \%$, before joiningCIGs to $7.4 \%$ $(\mathrm{p}=0.0001)$, after joining CIG.

3.3 Influence of CIG membership on volume of indigenous chicken products and by-products produced by small scale farmers

Paired simple t- test was used to test whether indigenous chicken products and by-products from indigenous chicken kept before CIG membership and as members had statistical difference. The products and by- product asked were the number of indigenous chicks, growers, hens, cocks eggs and kilograms of manure. Volume of both products and byproducts improved after joining CIG opposed to the volume before joining CIG. The mean number of chicks raised by 135 respondents before joining CIG was 8.73 chicks while after joining CIG the mean was 24.59 chicks. The mean number of growers kept by the respondents in a year before joining CIG was 5.59 while after joining CIG the mean number of growers kept was 21.98.T-test conducted revealed statistical significance in all the products, $\mathrm{p}<0.001$. This indicated a positive association of membership with the number of indigenous chicken products raised and kept.

Table 3: Paired t-test on influence of CIGs membership on indigenous chicken products and by-products

\begin{tabular}{|c|c|c|c|c|}
\hline & $\begin{array}{c}\text { Before } \\
\text { Joining } \\
\text { CIG }\end{array}$ & $\begin{array}{c}\text { After } \\
\text { Joining } \\
\text { CIG }\end{array}$ & $\begin{array}{c}\text { Mean } \\
\text { difference }\end{array}$ & $\begin{array}{c}\text { Paired sample } \\
\text { t- test (p-value) }\end{array}$ \\
\hline $\begin{array}{c}\text { Av. no. of chicks } \\
\text { raised }\end{array}$ & 8.73 & 8.73 & 15.86 & $<0.001$ \\
\hline $\begin{array}{c}\text { Av. no. of growers } \\
\text { raised }\end{array}$ & 5.99 & 5.99 & 15.99 & $<0.001$ \\
\hline $\begin{array}{c}\text { Av. no. Of hens } \\
\text { kept }\end{array}$ & 2.19 & 2.19 & 1.94 & $<0.001$ \\
\hline $\begin{array}{c}\text { Av. no. of cocks } \\
\text { kept }\end{array}$ & 1.04 & 1.04 & 0.57 & $<0.001$ \\
\hline $\begin{array}{c}\text { Av.kgs manure } \\
\text { collected }\end{array}$ & 0.71 & 0.71 & 1.81 & $<0.001$ \\
\hline
\end{tabular}




\section{International Journal of Science and Research (IJSR) \\ ISSN (Online): 2319-7064 \\ Index Copernicus Value (2013): 6.14 | Impact Factor (2014): 5.611}

3.4 Influence of CIG Membership on Annual Income from Indigenous Chicken Enterprise by Small Scale Farmer

The profit margin from indigenous chicken enterprise (before \& as member of CIG) was measured and calculated from the sales of Indigenous chicken products and by products less the costs incurred in purchasing farm inputs.Table 3gives the results. Mean veterinary cost before membership was ksh.73.12 while as a member the mean veterinary cost was Ksh. 502.85. The use of agricultural inputs is important if productivity is to be enhanced. Farmer groups are known to be avenues that facilitate and link farmers to new technologies and production practice [1].The mean sale of products before membership was Ksh. 1,632.605 while as members the mean sale was to Ksh. $3,920.666$ in a year. These results agree with findings by [6], that being in common interest groups can contribute more than $100 \%$ increase in productivity.

\section{Conclusions}

Common interest group members had much higher productivity as members than before membership with respect to, increased indigenous chicken products and income. From the results of the study, it is imperative to conclude that common interest group membership has influence on indigenous chicken productivity from smallholder farmers in Kisumu East Sub-County.

\section{Recommendations}

The study recommends the following:

1) Common Interest Group can be used alongside other extension approaches in a more systematic manner in improving indigenous chicken management practices

2) Common Interest Group can be used alongside other extension approaches in a more systematic manner in increasing the quantity of products and by-products from indigenous chicken.

3) Common Interest Group can be used alongside other extension approaches in a more systematic manner in increasing the income levels from indigenous chicken enterprise.

\section{Suggestions for Further Study}

According to results from the study on influence of CIG membership on productivity from indigenous chicken by smallholder farmers, there is need to carry out further research study on:

a) Factors affecting indigenous chicken Common Interest Group membership.

b) Factors influencing sustainability of CIG membership in indigenous chicken

\section{References}

[1] A., Adong, F. Mwaura., \&, G. Okoboi, What factors affect membership to farmer groups in Uganda?, (2012). Retrieved
http://ageconsearch.umn.edu/bitstream/126774/2/Adong WCover.pdf, on 23/3/2015.

[2] A., Agrawal. \& S, Goyal, Group size and collective action: Third-party monitoring in common-pool resources. Comparative Political Studies. (2010), 34(1):63-93

[3] A.,Kingori, A.Wachira, and JTuitoek. Indigenous Chicken Production in Kenya.(2010). International Journal of Poultry Science 9 (4): 309-316, 2010.

[4] E.F.Gueye, (2009). Women and Family Poultry Production in Africa. Development in Practice Journal 10:8-100

[5] H.AAklilu, C.J.MAlmekinders, H.M.J.Udo, and A.J.VanderZijpp, Village Poultry Consumption and Marketing in Relation to Gender, Religious festivals and Market access. Tropical Animal Health and Production 39 (3): 165-177, (2007).

[6] J.KManrid, A.Peter.and J.K.Wakhungu. Libaisi CIGs Youth Groups' contribution to Food Security in Western Kenya. Ministry of Agriculture Success Stories, Western Kenya.. (2012).

[7] M.Upton. The Livestock Revolution- Implication for Smallholder Agriculture. A case of milk and poultry production in Kenya. FAO, Livestock Policy Paper Discussion paper No. 1, (2000). URL http://www.socialresearchmethods.net/kb/> Accessed last 5th January 2014.

[8] Ministry of Agriculture, Livestock and Fisheries (MALF),Internal Impact Assessment of National Agriculture and Livestock Extension Programme Phase 1, NALEP(2007). Kenya: Nairobi Educational Press

[9] O.O.Joash. Influence of Common Interest Group strategy on Implementation of Crop Production Technologies; Nyando District, Nyanza(2010).

[10] R., Balakrishman. Barriers to Harness ICTs for the Advancement of Rural Women (2002). Accessed at http://www.fao.org/sd/2003/PE12033aon.htm. On $23 / 11 / 2015$

[11] R.J.Taiy,Characteristics of Common Interest Groups and Their Effectiveness in Empowering Smallholder Dairy Farmers in Uasin Gishu District, Kenya. MSC Thesis presented at Egerton University in October, (2009)

[12] Republic of Kenya,First Medium term plan (20082012), Kenya Vision 2030.A globally Competitive and prosperous Kenya Government printers, Nairobi Kenya,(2005).

[13] S .W.Njue, J.L.Kasiiti, and S.GGacheru.S.G, Assessing the economic impact of commercial Poultry feed supplementation and vaccination against Newcastle disease in local chicken in Kenya. Proceeding of a final research coordination meeting organized by the joint FAO/IAEA held in Vietnam, 24-28 May 2004, (2006).

[14] T.Yamane, Statistics, an Introductory Analysis, 2nd Ed., New York: Harper and Row, (1967).

[15] World Bank, Agriculture for Development. World development report. The World Bank, $1818 \mathrm{H}$ NW, Washington DC 20433, USA,(2008). Retrieved on $17 / 5 / 2014$

from siteresource.worldbank.org/INTWDR2008/...WDR-oobook.pdf 


\section{International Journal of Science and Research (IJSR) \\ ISSN (Online): 2319-7064}

Index Copernicus Value (2013): 6.14 | Impact Factor (2014): 5.611

\section{Author Profile}

Onyango Rose received a Diploma in Animal

Husbandry, BSc. and MSc. degrees in Livestock

Production and Agricultural Extension from Bukura

Agricultural College and Egerton University in 2003, 2012 and 2015,respectively. She is currently

Livestock Production Officer in Kisumu County, Kenya. 